\title{
OPTIMASI SINTESIS SENYAWA 1-(2,5-DIHIDROKSIFENIL)-(3-PIRIDIN-2-IL) PROPENON SEBAGAI ANTIINFLAMASI MENGGUNAKAN VARIASI KATALIS NaOH
}

\section{OPTIMIZATION OF SYNTHESIS OF 1-(2,5-DIHYDROXYPHENYL)-(3-PYRIDINE-2-YL)- PROPENONE, AN ANTI-INFLAMMATORY AGENT, USING NaOH}

\author{
Andy Eko Wibowo ${ }^{1}$, Andy Kurniawan Saputra ${ }^{1}$, Ratna Asmah Susidarti ${ }^{2}$ \\ ${ }^{1}$ Facultas Kedokteran dan ilmu Kesehatan, Universitas Muhammadiyah Yogyakarta, \\ Jl. Brawijaya, Tamantirto, Kasihan, Bantul 55183, Indonesia \\ ${ }^{2}$ Faculty of Pharmacy, Gadjah Mada University, \\ Jl. Sekip Utara, Sleman, Yogyakarta 55281, Indonesia \\ Email: andyew@umy.ac.id (Andy Eko Wibowo)
}

\begin{abstract}
ABSTRAK
Senyawa 1-(2,5-dihidroksifenil)-(3-piridin-2-il)-propenon merupakan senyawa kalkon yang memiliki aktifitas antiinflamasi sebanding dengan ibuprofen dan aktifitas antioksidannya sangat kuat setara dengan quercetin. Senyawa ini telah disintesis menggunakan 2,5-dihidroksiasetofenon dan piridin-2-karbaldehida dengan metode radiasi microwave dan katalis $\mathrm{K}_{2} \mathrm{CO}_{3}$ tanpa pelarut selama 4 menit. Dalam upaya memperoleh rendemen yang lebih baik, dilakukan penelitian dengan mengganti katalis, yaitu menggunakan katalis $\mathrm{NaOH}$. Penelitian dilakukan dengan mereaksikan senyawa 2,5-dihidroksiasetofenon dan piridin-2-karbaldehida dengan variasi katalis $\mathrm{NaOH}$ sebesar 0-0,002 mol. Senyawa disintesis menggunakan kekuatan radiasi microwave sebesar 140 watt selama 4 menit. Setelah proses sintesis maka dilakukan perhitungan rendemen senyawa 1-(2,5-dihidroksifenil)-(3-piridin-2-il)-propenon untuk mengetahui massa katalis $\mathrm{NaOH}$ yang optimal dalam menghasilkan rendemen terbanyak. Berdasarkan hasil yang didapat, massa katalis optimum untuk sintesis senyawa 1-(2,5-dihidroksifenil)-(3-piridin2-il)-propenon adalah 0,0010 mol dengan rendemen sebesar $13,23 \%$.
\end{abstract}

Kata kunci: 1-(2,5-dihidroksifenil)-(3-piridin-2-il)-propenon, kalkon, $\mathrm{K}_{2} \mathrm{CO}_{3}, \mathrm{NaOH}$, microwave, optimasi. 


\begin{abstract}
1-(2,5-dihydroxyphenyl)-(3-pyridine-2-yl)-propenone is a chalcone with antiinflammatory activity comparable to that ibuprofen and antioxidant activity equivalent to quercetin. This compound can be synthesized using 2,5-dihydroxyacetophenone and pyridine-2-carboxaldehyde with microwave radiation method and catalyst of $\mathrm{K}_{2} \mathrm{CO}_{3}$ without any solvent in 4 minutes. To obtain the higher yield, the catalyst is replaced by $\mathrm{NaOH}$. 1-(2,5-dihydroxyphenyl)-(3-pyridine-2-yl)-propenone was synthesized from 2,5dihydroxyacetophenone and pyridine-2-carboxaldehyde with variation of $\mathrm{NaOH}$ from 0 $0.002 \mathrm{~mol}$, and then the yield of 1-(2,5-dihydroxyphenyl)-(3-pyridine-2-yl)-propenone was calculated to obtain the optimal mass of $\mathrm{NaOH}$. Based on the result, optimal mass of $\mathrm{NaOH}$ for the synthesis of 1-(2,5-dihydroxyphenyl)-(3-pyridine-2-yl)-propenone is 0.0010 mol that generated $13.23 \%$ of yield.
\end{abstract}

Key words: chalcone, 1-(2,5-dihydroxyphenyl)-(3-pyridine-2-yl)-propenone, $\mathrm{NaOH}, \mathrm{K}_{2} \mathrm{CO}_{3}$, microwave, optimization. 


\section{Pendahuluan}

Kalkon adalah senyawa yang biasa terdapat pada tumbuhan dan merupakan salah satu prekursor dari flavonoid atau isoflavon (Jamal et al., 2009; Kalirajan et al., 2009). Senyawa kalkon memiliki aktifitas farmakologi sebagai antibakteri, antifungi, antiinflamasi, antioksidan, antihiperglikemik, dan immunodulator (Kishor et al., 2010).

Sintesis obat merupakan bagian dasar dari proses dan penemuan obat. Tanpa adanya proses ini, industri obat tidak akan berkembang seperti sekarang. Dalam sintesis, untuk mengetahui banyaknya produk yang disintesis dapat diketahui melalui hasil rendemen senyawa obat tersebut. Rendemen adalah jumlah produk yang diperoleh dalam reaksi kimia (Vogel et al., 1996). Hasil teoritis dari rendemen dihitung dengan perhitungan stoikiometri berdasarkan jumlah mol dari semua reaktan. Rendemen yang ideal adalah 100\%, jika rendemen suatu senyawa di atas $90 \%$ maka disebut excellent, untuk nilai rendemen di atas $80 \%$ disebut very good, selanjutnya jika didapat nilai rendemen sebanyak $70 \%$ maka dapat disebut good, di atas 50\% disebut fair dan di bawah $40 \%$ disebut poor (Vogel et al., 1996).

Senyawa 1-(2,5-dihidroksifenil)(3-piridin-2-il)-propenon adalah turunan senyawa kalkon yang disintesis dari 2,5dihidroksiasetofenon dan piridin-2karbaldehida dengan metode radiasi microwave selama 4 menit menggunakan power microwave 140 watt dan katalis $\mathrm{K}_{2} \mathrm{CO}_{3}$ tanpa pelarut. Hasil rendemen yang didapat tergolong dalam kategori fair yaitu sebesar 54\% (Wibowo, 2013). Pemilihan metode ini telah tepat dalam sisi industri karena reaksi lebih singkat, mudah penanganannya, dan tanpa pelarut. Karena nilai rendemen yang masih tergolong fair maka dari itu perlu dilakukan optimasi pada senyawa 1-(2,5dihidroksifenil)-(3-piridin-2-il)-propenon dengan mengganti katalis $\mathrm{K}_{2} \mathrm{CO}_{3}$ menjadi $\mathrm{NaOH}$. Katalis $\mathrm{NaOH}$ merupakan salah satu katalis yang sering digunakan untuk sintesis senyawa kalkon, katalis ini memiliki keuntungan dapat menurunkan operating temperature dan menurunkan konsumsi panas (Lawrence et al., 2006; Kumar et al., 2012). Senyawa kalkon benzyldeneacetophenone yang disintesis oleh Patil et al. (2009) dengan katalis $\mathrm{NaOH}$ dan $\mathrm{K}_{2} \mathrm{CO}_{3}$ didapat masing-masing rendemen senyawa tersebut adalah $85 \%$ 
dan $70 \%$, ini membuktikan bahwa katalis

$\mathrm{NaOH}$ dapat mensintesis senyawa kalkon dan menghasilkan jumlah rendemen yang lebih besar dibanding katalis $\mathrm{K}_{2} \mathrm{CO}_{3}$ Oleh karena itu dilakukan usaha untuk mensintesis senyawa 1-(2,5dihidroksifenil)-(3-piridin-2-il)-propenon dengan katalis $\mathrm{NaOH}$ untuk mendapatkan rendemen yang lebih baik dibanding $\mathrm{K}_{2} \mathrm{CO}_{3}$.

\section{Metode Penelitian}

\section{Alat dan Bahan}

Alat-alat yang digunakan dalam penelitian yaitu: Beaker glass (Pyrex), corong kaca (Pyrex), kertas saring, pipet tetes, microwave (LG I-Wave MS204200), mortir-stamper kaca, panci, timbangan analitik, sendok pengaduk dan penangas air (Maspion). Bahanbahan yang digunakan pada penelitian ini yaitu 2,5-dihidroksiasetofenon (Sigma), 2-piridin-karbaldehida (Sigma), $\mathrm{NaOH}$ (Merck), akuades, dan etanol (Merck).

\section{Jalannya Penelitian}

1. Sintesis senyawa 1-(2,5dihidroksifenil)-(3-piridin-2-il)propenon

$$
\text { Sintesis senyawa 1-(2,5- }
$$

dihidroksifenil)-(3-piridin-2-il)-

propenon dalam penelitian ini mengadopsi metode yang digunakan oleh Wibowo (2013). Sebanyak 0,152 gram $\quad(0,001 \quad \mathrm{~mol}) \quad 2,5-$ dihidroksiasetofenon ditimbang kemudian dicampurkan dengan 0,040 gram $(0,001 \mathrm{~mol})$ katalis $\mathrm{NaOH}$ hingga homogen dalam mortir. Lalu sebanyak $100 \mu \mathrm{l} \quad(0,001 \quad \mathrm{~mol})$ piridin-2karbaldehida diteteskan dalam padatan dan dicampur hingga homogen. Campuran dimasukkan dalam microwave dengan power sebesar 140 watt dan waktu reaksi selama 4 menit. Hasil reaksi berupa padatan berwarna coklat kemudian didiamkan hingga dingin, lalu ditambahkan sedikit etanol untuk melarutkan senyawa 2,5dihidroksiasetofenon, setelah itu dicuci dengan akuades untuk menghilangkan starting material piridin-2-karbaldehida dan $\mathrm{NaOH}$. Maka akan diperoleh padatan berwarna merah yang kemudian disaring menggunakan kertas saring. Padatan dibiarkan sampai kering. Padatan yang telah kering kemudian direkristalisasi dengan etanol. Proses ini dimaksudkan untuk menghilangkan pengotor dan senyawa pengganggu lainnya. Setelah beberapa menit endapan kristal disaring kembali, 
maka akan didapatkan senyawa 1-

(2,5-dihidroksifenil)-(3-piridin-2-il)-

propenon murni. Senyawa 1-(2,5-

dihidroksifenil)-(3-piridin-2-il)-

propenon yang dihasilkan ditimbang,

kemudian dihitung rendemennya.

2. Pengaruh katalis $\mathrm{NaOH}$ terhadap

rendemen senyawa 1-(2,5-

dihidroksifenil)-(3-piridin-2-il)-

propenon

Untuk mengetahui pengaruh katalis $\mathrm{NaOH}$ terhadap rendemen senyawa 1-(2,5-dihidroksifenil)-(3piridin-2-il)-propenon, maka dilakukan eksperimen sintesis senyawa 1-(2,5dihidroksifenil)-(3-piridin-2-il)propenon dengan berbagai variasi massa katalis $\mathrm{NaOH}$ sebesar 0 ; 0,00025; 0,00050; 0,00075; 0,001; 0,00125; dan 0,002 mol dengan kekuatan microwave sebesar 140 watt selama 4 menit. Masing-masing variasi dilakukan replikasi sebanyak 3 kali dan dilakukan penimbangan hasil rendemennya untuk mendapatkan massa katalis $\mathrm{NaOH}$ yang optimum.

\section{Hasil dan Pembahasan}

Optimasi massa katalis $\mathrm{NaOH}$

pada sintesis senyawa 1-(2,5dihidroksifenil)-(3-piridin-2-il) propenon dilakukan dengan cara kerja yang sama tetapi dilakukan percobaan dengan berbagai variasi massa $\mathrm{NaOH}$ yaitu massa katalis $\mathrm{NaOH}$ sebesar 0,010 gram $(0,00025 \mathrm{~mol}) ; 0,020$ gram $(0,0005 \mathrm{~mol}) ;$ 0,030 gram $(0,00075 \mathrm{~mol}) ; 0,040$ gram (0,001 mol); 0,050 gram $(0,00125 \mathrm{~mol})$; 0,080 gram $(0,002 \mathrm{~mol})$, dan tanpa katalis. Eksperimen dilakukan pada power microwave 140 watt dan waktu reaksi selama 4 menit. Data rendemen yang didapat dari eksperimen yang telah dilakukan dapat dilihat pada Gambar 1.

Peningkatan rendemen senyawa sintesis terjadi karena adanya penambahan katalis $\mathrm{NaOH}$. Pada massa katalis sebesar 0,001 mol merupakan massa katalis yang menghasilkan rendemen terbesar, hal ini mungkin terjadi karena penambahan konsentrasi katalis akan mempercepat reaksi. Kecepatan ini akan meningkat sampai pada titik konsentrasi tertentu dimana reaksi tidak dapat menjadi lebih cepat lagi atau disebut konsentrasi optimum katalis. Sementara itu pada massa katalis sebesar 0,002 mol terjadi perubahan warna hitam pada senyawa atau terjadi dekomposisi. Hal ini diprediksi karena banyaknya terjadi tabrakan antar molekul sehingga menghasilkan suatu hasil pembakaran. Gambar 1 menunjukkan bahwa penambahan katalis yang optimum adalah sebesar 
0,001 mol, namun dengan terjadinya penambahan katalis yang melebihi konsentrasi optimum maka akan mengurangi jumlah rendemen senyawa 1-(2,5-dihidroksifenil)-(3-piridin-2-il) propenon. Dari hasil yang diperoleh perlu dilakukan optimasi terhadap perbandingan senyawa katalis lainnya yang dapat digunakan untuk sintesis senyawa target agar didapatkan rendemen dalam jumlah besar.

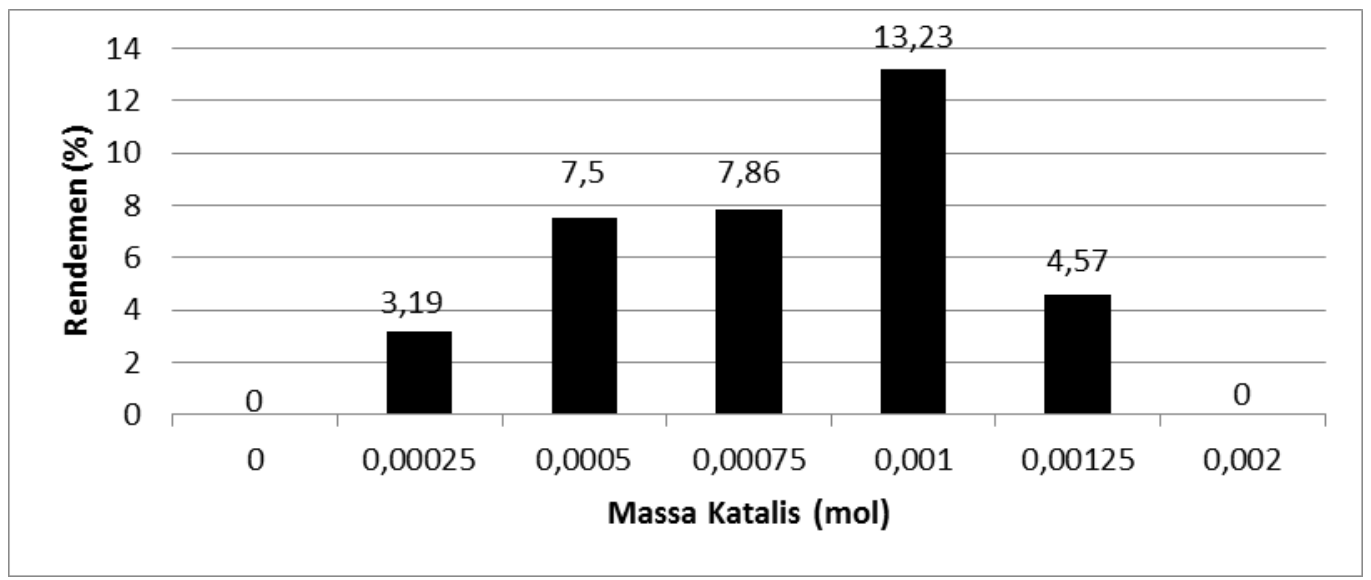

Gambar 1. Pengaruh massa katalis terhadap rendemen.

\section{Kesimpulan}

Rendemen terbesar sintesis

senyawa 1-(2,5-dihidroksifenil)-(3-

piridin-2-il) propenon dengan

menggunakan katalis $\mathrm{NaOH}$ adalah sebesar 13,27\% dengan massa katalis $\mathrm{NaOH}$ sebesar 0,001 mol.

\section{Daftar Pustaka}

Jamal, H., Ansari, W., Rizvi, S. 2009. Evaluation of chalcones-a flavonoid subclass, for, their anxiolytic effects in rats using elevated plus maze and open field behaviour tests. Fundamental and Clinical Pharmacology, 22(6):67381.

Kalirajan, R., Sivakumar, S.U., Jubie, S., Gowramma, B., Suresh, B. 2009. Synthesis and biological evaluation of some heterocyclic derivatives of chalcones. International Journal of ChemTech Research, 1(1):27-34.

Kumar, S., Drozd, V., Saxena, S.K. 2012. Catalytic studies of sodium hydroxide and carbon monoxide reaction. Catalysts, 2:532-543.

Kishor, V.G., Sandip, V.G., Satish, B.J., Shantilal D.R. 2010. Synthesis of 
some novel chalcones of phthalimidoester possessing good antiinflamatory and antimicrobial activity. Indian Journal of Chemistry, 49B:131-136.

Lawrence, N.J., Armitage, S.M., Greedy, B., Cook, D., Ducki, S., McGown, A.T. 2006. The synthesis of indanones related to combretastatin A-4. Tetrahedron Letters, 47(10):1637-1640.

Patil, C.B., Mahajan, S.K., Katti, S.A. 2009. Chalcone: a versatile molecule. Journal of Pharmaceutical Sciences and Research, 1(3):11-22.

Vogel, A.I., Tatchell, A.R., Furnis, B.S., Hannaford, A.J., Smith, P.W.G. 1996. Vogel's Textbook of Practical Organic Chemistry. Edisi kelima. New York: John Wiley \& Sons.

Wibowo, A.E. 2013. Sintesis dan uji aktifitas antiinflamasi senyawa 1(2,5-dihidroksifenil)-(3-piridin-2-il)propenon. Tesis. Program Studi Ilmu Farmasi, Fakultas Farmasi, Universitas Gajah Mada. 